\title{
Socio-demographic patterning of the individual-level double burden of malnutrition in a rural population in South India: a cross-sectional study
}

\author{
Matthew Little ${ }^{1,2^{*}}$, Sally Humphries ${ }^{3}$, Warren Dodd ${ }^{1,4}$, Kirit Patel $\left.\right|^{5}$ and Cate Dewey ${ }^{1}$
}

\begin{abstract}
Background: The double burden of malnutrition is the co-occurrence of undernutrition (e.g. underweight, stunting, and micronutrient deficiencies) and over-nutrition (e.g. obesity, type 2 diabetes, and cardiovascular disease) at the population, household, or individual level. The objectives of this study were to determine the extent and determinants of individual-level co-morbid anemia and overweight and co-morbid anemia and diabetes in a population in rural Tamil Nadu, South India.

Methods: We undertook a cross-sectional study of adults $(n=753)$ in a rural region of Tamil Nadu, South India. A survey assessed socio-demographic factors, physical activity levels, and dietary intake. Clinical measurements included body-mass index, an oral glucose tolerance test, and blood hemoglobin assessments. Multivariable logistic regression analyses were used to determine associations between risk factors and two co-morbid double burden pairings: (1) anemia and overweight, and (2) anemia and diabetes.

Results: Prevalence of co-morbid anemia and overweight was $23.1 \%$ among women and $13.1 \%$ among men. Prevalence of co-morbid anemia and diabetes was 6.2\% among women and 6.3\% among men. The following variables were associated with co-morbid anemia and overweight in multivariable models [odds ratio ( $95 \%$ confidence interval)]: female sex $[2.3(1.4,3.85)]$, high caste $[3.2(1.34,7.49)]$, wealth index $[1.1(1.00,1.12)]$, rurality $(0.7[0.56,0.85])$, tobacco consumption $[0.6(0.32,0.96)]$, livestock ownership $[0.5(0.29,0.89)]$, and energy-adjusted meat intake $[1.8(0.61,0.94)]$. The following variables were associated with co-morbid anemia and diabetes in multivariable models: age [1.1 (1.05, $1.11)]$, rurality $[0.8(0.57,0.98)]$, and family history of diabetes $[4.9(1.86,12.70)$.

Conclusion: This study determined the prevalence and factors associated with individual-level double burden of malnutrition. Women in rural regions of India may be particularly vulnerable to individual-level double burden of malnutrition and should be a target population for any nutrition interventions to address simultaneous over- and undernutrition.
\end{abstract}

Keywords: India, Rural, Malnutrition, Anemia, Overweight, Obesity, diabetes, Undernutrition, Over-nutrition, Double burden

\footnotetext{
* Correspondence: matthewlittle@uvic.ca

'Department of Population Medicine, University of Guelph, Guelph, ON

Canada

${ }^{2}$ School of Public Health and Social Policy, University of Victoria, Victoria, BC, Canada

Full list of author information is available at the end of the article
}

(c) The Author(s). 2020 Open Access This article is licensed under a Creative Commons Attribution 4.0 International License, which permits use, sharing, adaptation, distribution and reproduction in any medium or format, as long as you give appropriate credit to the original author(s) and the source, provide a link to the Creative Commons licence, and indicate if changes were made. The images or other third party material in this article are included in the article's Creative Commons licence, unless indicated otherwise in a credit line to the material. If material is not included in the article's Creative Commons licence and your intended use is not permitted by statutory regulation or exceeds the permitted use, you will need to obtain permission directly from the copyright holder. To view a copy of this licence, visit http://creativecommons.org/licenses/by/4.0/. The Creative Commons Public Domain Dedication waiver (http://creativecommons.org/publicdomain/zero/1.0/) applies to the data made available in this article, unless otherwise stated in a credit line to the data. 


\section{Background}

Low- and middle-income countries (LMICs) around the globe are undergoing a nutrition transition, characterized by shifting dietary and physical activity patterns [1-3]. In India, dietary changes include increased intakes of vegetable oils, refined grains, and processed foods, as well as reduced consumption of legumes and coarse cereals $[4,5]$. Levels of inactivity are also rising as manual labour is replaced by sedentary work, and leisure activities remain relatively inaccessible and unpopular [4]. The combined result of such dietary and lifestyle changes has been a population-level increase in over-nutrition leading to obesity and associated diseases. Indeed, prevalence of obesity and overweight increased in excess of $125 \%$ from 2003 to 2015 and is currently $30-40 \%$ in some urban populations and $15-30 \%$ in some rural populations $[6,7]$. Consequently, obesity-related cardio-metabolic diseases are becoming severe public health concerns in India; for example, prevalence of type 2 diabetes is $10-18 \%$ in urban and $5-13 \%$ in rural populations [8-10], while mortality due to ischemic heart disease and stroke account for $21 \%$ of all deaths [11].

Meanwhile, despite rapid economic development and associated dietary and lifestyle changes, many regions of India continue to experience poverty, food insecurity, and poor access to health services, which contribute to persistent problems of undernutrition and related deficiencies. India has the highest number of severely undernourished people in the world (190 million), representing $15 \%$ of its entire population [12]. Approximately $23 \%$ of women and $20 \%$ of men (age 15-49) are underweight [7]. Additionally, micronutrient deficiencies and associated disorders affect a large portion of the population, particularly in rural regions, where $70 \%$ of Indians reside [7, 13]. In particular, iron-deficiency anemia affects $53.1 \%$ of women of childbearing age and is a widely used marker of undernutrition [7].

The combined burdens of overweight and obesityrelated diseases, in addition to undernutrition and micronutrient deficiencies, is called the 'double burden' of malnutrition. This double burden is common in LMICs undergoing the nutrition transition and has been reported in Latin America [14-16], South Asia [17], Southeast Asia [2, 18], Eastern Europe [2], and Africa [19, 20]. In India, the double burden of malnutrition is well-established at the national level [7]; however, the co-occurrence of overnutrition and undernutrition also exists at the household and individual levels $[21,22]$. Individual-level double burden may occur when a person experiences co-morbid indicators of over-nutrition (e.g. obesity, type 2 diabetes, and cardiovascular disease) and undernutrition (e.g. underweight, stunting, and micronutrient deficiencies). Yet, the individual-level double burden of malnutrition has received limited attention by researchers, especially in rural regions of India where poverty, food insecurity, and poor access to healthcare services are pervasive despite rapid changes in diets, lifestyles, and livelihoods [23]. Against this backdrop, this cross-sectional study had two objectives. First, we evaluated the extent of the individuallevel double burden of malnutrition in a rural region of northwestern Tamil Nadu, India by assessing two comorbidities: (1) anemia and overweight; and (2) anemia and diabetes. Second, we determined associations between these co-morbidities and several socio-economic, environmental, dietary, and lifestyle factors. Overall, we aim to contribute to research on the severity and determinants of the individual-level double burden of malnutrition in rural South India.

\section{Methods}

\section{Study design and sample}

We conducted a cross-sectional study in 18 villages in Anchetty and Madakkal panchayats (townships) in the Krishnagiri district, in northwestern Tamil Nadu (Fig. 1). Both Tamil and Kannada are spoken in the study region due to its proximity to Karnataka. The Krishnagiri district is ranked as one of the poorest districts in Tamil Nadu, with high illiteracy, low gross district domestic product, and a low gender development index compared to other districts in Tamil Nadu [24]. Within the study site, rates of illiteracy and poverty are higher than the district averages; $48.3 \%$ of adults are illiterate and 36\% live below the poverty line [25].

Details of the study design are described elsewhere [26]. Briefly, recruitment of individuals occurred through a randomized two-stage method, in which we approached a random sample of $8 \%$ of households in the sampling frame, then employed World Health Organization (WHO) Kish method to select a single household member ( $>19$ years of age) for the study [27]. Pregnant women were excluded. During follow-up appointments with participants, we collected data on descriptive characteristics using a semi-quantitative survey, dietary intake using a validated food frequency questionnaire (FFQ) [28], and physical activity habits using the WHO's global physical activity questionnaire (GPAQ) [29].

\section{Clinical measurements, definitions, and variables}

Weight, height, waist circumference, and hip circumference were measured for each participant using standardized techniques and body mass index $\left(\mathrm{BMI}, \mathrm{kg} / \mathrm{m}^{2}\right)$ was calculated [30]. Blood pressure was recorded as the average of two readings taken on the right arm in the sitting position with a portable OMRON BP-760 electronic blood pressure monitor (Omron Healthcare, Hoofddorp, Netherlands). Glucose tolerance was determined using an oral glucose tolerance test. After an 8-h minimum overnight fast, we measured fasting capillary blood 


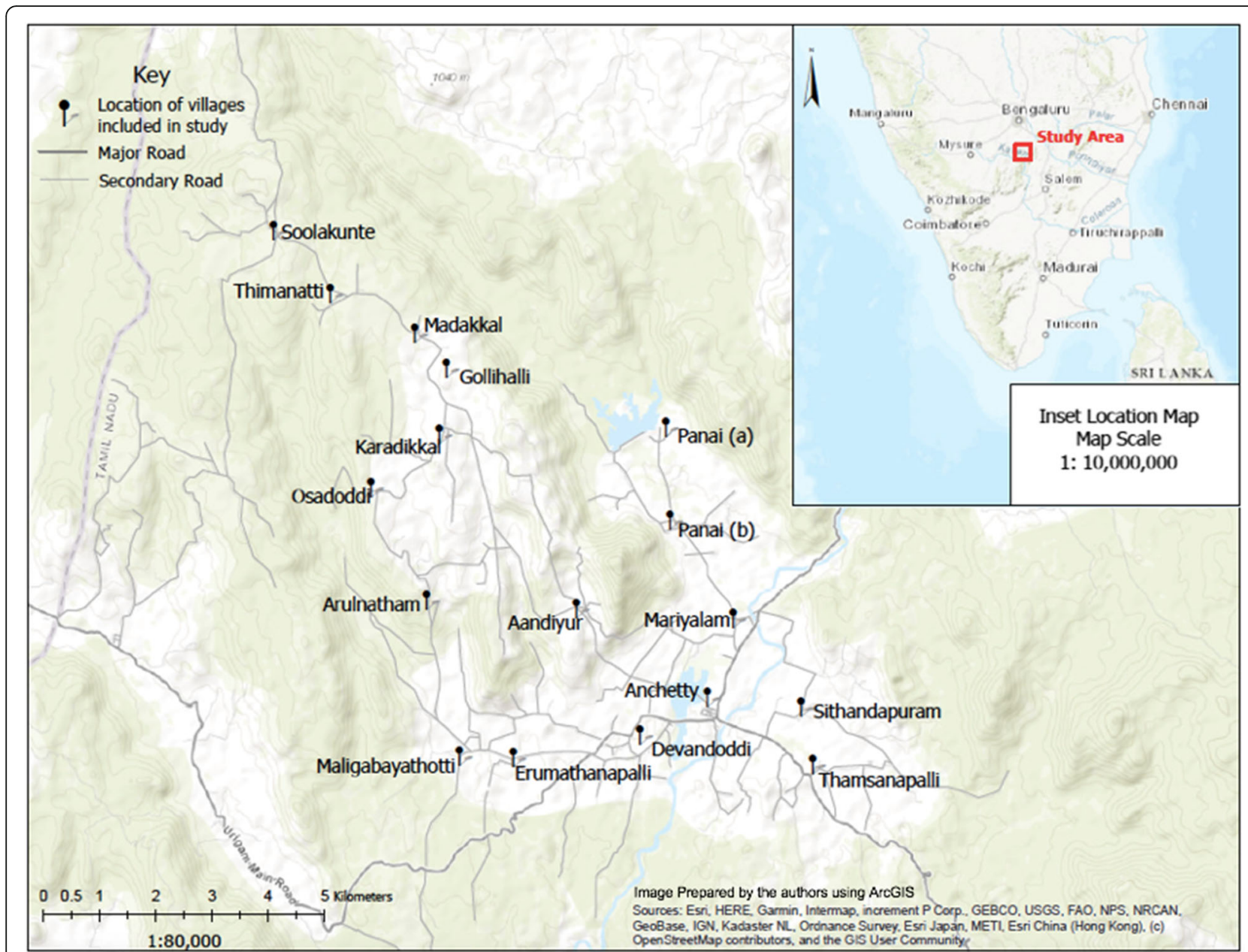

Fig. 1 Location of study area and villages included in the study

glucose (CBG) with a One Touch Ultra glucometer (Johnson \& Johnson, Milpitas, CA, USA). Oral glucose (75 $\mathrm{g}$ anhydrous) was administered and consumed within $5 \mathrm{~min}$. Two hours later, we measured post-load CBG [31]. Blood hemoglobin $(\mathrm{Hb})$ concentration was assessed using capillary blood samples and a HemoCue ${ }^{\circ} \mathrm{HB} 201+$ analyzer (Hemocue AB, Angelholm, SE).

Participants were categorized into BMI classes using the cut-offs for Asian populations: underweight $(<18.5$ $\left.\mathrm{kg} / \mathrm{m}^{2}\right)$; normal $\left(\geq 18.5 \mathrm{~kg} / \mathrm{m}^{2}\right.$ and $\left.<23 \mathrm{~kg} / \mathrm{m}^{2}\right)$; overweight $\left(\geq 23 \mathrm{~kg} / \mathrm{m}^{2}\right.$ and $\left.<25 \mathrm{~kg} / \mathrm{m}^{2}\right)$; obesity class I $(\geq 25$ $\mathrm{kg} / \mathrm{m}^{2}$ and $\left.<30 \mathrm{~kg} / \mathrm{m}^{2}\right)$; and obesity class II $\left(\geq 35 \mathrm{~kg} / \mathrm{m}^{2}\right)$ [32]. Abdominal obesity was defined as waist circumference $\geq 90 \mathrm{~cm}$ for men and $\geq 80 \mathrm{~cm}$ for women [33]. Consistent with previous studies [21,34], participants were classified as stunted if their height was $<-2$ Z-scores below the sex-specific reference population at 18 years of age, calculated as $<163.6 \mathrm{~cm}$ for men and $<151.8 \mathrm{~cm}$ for women [35]. High blood pressure was defined as mean systolic blood pressure $\geq 140 \mathrm{mmHg}$ and/or mean diastolic blood pressure $\geq 90 \mathrm{mmHg}$ and/or self-reported treatment with blood pressure medication [36]. As per WHO criteria, diabetes was defined as individuals with proof of previous diagnosis and/or fasting CBG $\geq 7$ $\mathrm{mmol} / \mathrm{L}(\geq 126 \mathrm{mg} / \mathrm{dl})$ and $/$ or a $2 \mathrm{~h}$ post prandial CBG value $\geq 12.2 \mathrm{mmol} / \mathrm{L} \quad(\geq 220 \mathrm{mg} / \mathrm{dL})$ [31]. Impaired glucose tolerance (IGT) was defined as a fasting CBG $<7$ $\mathrm{mmol} / \mathrm{L}$ and a 2 -h post glucose $\mathrm{CBG} \geq 8.9 \mathrm{mmol} / \mathrm{L}$ $(\geq 160 \mathrm{mg} / \mathrm{dL})$ but $<12.2 \mathrm{mmol} / \mathrm{L}(220 \mathrm{mg} / \mathrm{dL})$ [31]. Impaired fasting glucose (IFG) was defined as a fasting CBG $\geq 6.1 \mathrm{mmol} / \mathrm{L}(\geq 110 \mathrm{mg} / \mathrm{dL})$ and $<7 \mathrm{mmol} / \mathrm{L}(<126$ $\mathrm{mg} / \mathrm{dL}$ ) and a $2 \mathrm{~h}$ post-glucose CBG $<8.9 \mathrm{mmol} / \mathrm{L}(<$ $160 \mathrm{mg} / \mathrm{dL}$ ). Pre-diabetes was defined as the existence of IGT or IFG or co-occurrence of both. Mild anemia was defined as blood $\mathrm{Hb}$ concentration $110-129 \mathrm{~g} / \mathrm{L}$ for men and $110-119 \mathrm{~g} / \mathrm{L}$ for women. Moderate and severe anemia were defined as blood $\mathrm{Hb}$ concentration 80-109 $\mathrm{g} / \mathrm{L}$ and $<80 \mathrm{~g} / \mathrm{L}$ respectively for both men and women.

Socioeconomic status (SES) was determined with an asset-based wealth index (hereafter referred to as wealth index) using a subset of 13 of 29 questions taken from the Standard of Living Index developed by the 
International Institute of Population Sciences (IIPS) for use in their National Family and Health Surveys (NFHS) [37]. Attributes and possessions were weighted for a maximum score of 41 using weights developed by the IIPS [38]. Higher values were therefore indicative of a greater household asset base. Caste was categorized as low caste (comprised of scheduled castes and scheduled tribes), middle caste (comprised of other backward castes and most backward castes), high caste (Brahmin caste), or not applicable (in the case of non-Hindu religion).

\section{Data analysis}

Food frequency questionnaire data were processed with $\mathrm{EpiNu}^{\circ}$ (Madras Diabetes Research Foundation, Chennai, $\mathrm{TN}$, IN), which provided information on caloric consumption (kilocalories per day) and average daily macroand micronutrient intake (grams per day). Nutrient intake variables were scaled to grams per $1000 \mathrm{kcal}$ to account for differences in energy intake between participants. Physical activity scores were calculated using WHO's GPAQ Analysis Guide, which provided a total measure of metabolic equivalent minutes per week [29]. Values were scaled to hours per day of moderate physical activity. Sedentary time was defined as hours spent sitting per day and television time was defined as hours spent watching television per day. We calculated a rurality index value for each individual and standardized these values to a mean of zero and a SD of one, adapted from Weinert \& Boik [39]. A higher rurality index value represented the product of a greater degree of remoteness and lower population density of home village.

Statistical analyses were completed in STATA Version 13.0 (StataCorp, College Station, TX, USA). Clinical and sociodemographic characteristics of the study population were tabulated and compared by sex using Student's ttests for means and Pearson chi-squared tests for proportions. We calculated sex-specific prevalence of indicators of over-nutrition (overweight, obese class I, obese class II, pre-diabetes, diabetes, high blood pressure, and abdominal obesity) and undernutrition (underweight, mild anemia, moderate anemia, severe anemia, and stunted). Prevalence values were age- and sex-standardized using state-level age and sex data from the 2011 national census [40]. We then calculated sex-specific prevalence of two double burden pairs (DBP); DBP1 was co-morbid anemia and overweight or obese and DBP2 was co-morbid anemia and type 2 diabetes. We created a four-level categorical variable for each DBP. For DBP1, these categories were: $0=$ neither anemia nor overweight/obese (referent); $1=$ anemia only; 2 = overweight $/$ obese only; and $3=$ co-morbid anemia and overweight/obese. For DBP2, these categories were: $0=$ neither anemia nor diabetes (referent); $1=$ anemia only; 2 =diabetes only; and $3=$ co-morbid anemia and diabetes. We calculated means and proportions of a variety of demographic, wealth, physical activity, and dietary characteristics for each category level. Differences in means and proportions were assessed using oneway analysis of variance (ANOVA) and Pearson's chisquared tests, respectively. If these tests yielded a statistically significant test result $(p<0.05)$, we employed a Sidak pairwise comparison to determine which categories were different from each other.

Using the logit command in STATA, we conducted a backward stepwise model-building process to develop multinomial logistic regression models using the categories of each DBP as dependent variables. We therefore built a total of three models for each DBP using the same method. First, age- and sex-adjusted bivariate models were assessed to determine factors associated with the outcome at a liberal $p$-value of 0.2 with anemia, overweight, and co-morbid anemia and overweight (for DBP1 model) or anemia, diabetes, and co-morbid anemia and diabetes (for DBP2 model). Factors that were associated at the liberal p-value were then included in initial multivariable logistic regression models. We eliminated non-significant variables using a p-value cutoff of 0.05 from each model, assuming no confounding if coefficients of remaining variables changed by less than $20 \%$ after removal of the variable. Quadratic terms and interaction terms were assessed if there was biological or practical justification. Multicollinearity was assessed in all models but was not determined to be present. All models were adjusted for age and sex.

\section{Results}

A total of 812 individuals were recruited for the study. Of these, 753 ultimately participated, including 341 men and 412 women. Response rate was $87.4 \%$ among men and $99.2 \%$ among women. In total, 752 (92.6\%) completed a FFQ and 749 (92.2\%) participated in the oral glucose tolerance test and submitted capillary blood samples for hemoglobin assessment. The mean age of participants was 47 (range 20-92). Over three-quarters (75.7\%) of women were illiterate, compared to just over half $(50.4 \%)$ of men. On average, men were more educated than women as measured by years of schooling.

Sex-specific unadjusted clinical and sociodemographic characteristics are presented in Table 1. Age- and sexstandardized prevalence of underweight, overweight, obesity class I, and obesity class II among the study population were $22.7,14.9,16.1$, and $3.3 \%$ respectively. Age- and sex-standardized prevalence of IFG, IGT, and type 2 diabetes were $3.9,5.6$, and $10.8 \%$ respectively. Of those with type 2 diabetes, $56.4 \%$ were previously undiagnosed. Age- and sex-standardized prevalence of mild, moderate, and severe anemia were 19.9, 22.6, and $4.8 \%$ respectively. Anemia (mild, moderate, or severe) 
Table 1 Sex-specific clinical and sociodemographic characteristics of a sample of adults (> 19 years) in rural South India

\begin{tabular}{|c|c|c|c|c|c|}
\hline Characteristic & $\begin{array}{l}\text { Men } \\
n\end{array}$ & Mean (SD) or \% & $\begin{array}{l}\text { Women } \\
\mathrm{n}\end{array}$ & Mean (SD) or \% & $\boldsymbol{p}$-value \\
\hline Age (y) & & & & & 0.10 \\
\hline $20-34$ & 69 & 20.2 & 95 & 23.1 & \\
\hline $35-49$ & 115 & 33.6 & 147 & 35.7 & \\
\hline $50-64$ & 105 & 30.7 & 111 & 26.9 & \\
\hline $65+$ & 52 & 15.2 & 58 & 14.1 & \\
\hline Height (cm) & 340 & $165(7.0)$ & 407 & $154(6.6)$ & $<0.001$ \\
\hline Stunting (men/women< 163.6/151.8cm) & 120 & 35.3 & 129 & 31.7 & 0.26 \\
\hline Body Mass Index (kg/m²) (BMI) & 340 & $21.6(3.91)$ & 406 & $22.0(4.49)$ & 0.10 \\
\hline \multicolumn{6}{|l|}{ BMI Categories } \\
\hline Underweight (<18.5) & 84 & 24.7 & 85 & 20.9 & \\
\hline Normal weight $(\geq 18.5 \&<23 \mathrm{~kg} / \mathrm{m})$ & 139 & 40.9 & 162 & 39.9 & \\
\hline Overweight ( $\geq 23$ and < 25 kg/m²) & 56 & 16.5 & 62 & 15.2 & \\
\hline Obese class I ( $\geq 25$ and $<30 \mathrm{~kg} / \mathrm{m} 2$ & 55 & 16.2 & 77 & 19.0 & \\
\hline Obese class II ( $\geq 30$ kg/m2) & 6 & 1.8 & 20 & 4.9 & \\
\hline Waist circumference $(\mathrm{cm})$ & 337 & $82(11.3)$ & 407 & $78(12.5)$ & $<0.001$ \\
\hline \multicolumn{6}{|l|}{ Abdominal obesity categories (waist circumference) } \\
\hline Non-obese (men/women < $90 /<80 \mathrm{~cm}$ ) & 252 & 74.8 & 236 & 58.0 & \\
\hline Obese (men/women $\geq 90 / \geq 80 \mathrm{~cm}$ ) & 85 & 25.2 & 171 & 42.0 & \\
\hline Hemoglobin $(\mathrm{Hb})(\mathrm{g} / \mathrm{dL})$ & 336 & $13.4(2.48)$ & 407 & $11.5(5.77)$ & $<0.001$ \\
\hline \multicolumn{6}{|l|}{ Anemia (Hb concentrations) } \\
\hline No (men/women $\geq 130 / \geq 120 \mathrm{~g} / \mathrm{dL}$ ) & 215 & 64.0 & 171 & 42.0 & \\
\hline Mild anemia (men/women 110-129/110-119 g/dL) & 75 & 22.3 & 74 & 18.2 & \\
\hline Moderate anemia (men/women 80-109/70-109 g/dL) & 37 & 11.0 & 148 & 36.4 & \\
\hline Severe anemia (men/women $<80 /<70 \mathrm{~g} / \mathrm{dL}$ ) & 9 & 2.7 & 14 & 3.4 & \\
\hline $\begin{array}{l}\text { High blood pressure ( } \mathrm{SBP} \geq 140 \mathrm{mmHg} \text { and/or } \\
\mathrm{DBP} \geq 90 \mathrm{mmHg} \text { and/or treatment with blood } \\
\text { pressure medication) }\end{array}$ & 105 & 31.1 & 117 & 28.8 & 0.51 \\
\hline \multicolumn{6}{|l|}{ Glucose tolerance and diabetes } \\
\hline Impaired fasting glucose (fasting CBG 6.1-6.9 mmol/L) & 8 & 2.4 & 17 & 4.2 & 0.17 \\
\hline $\begin{array}{l}\text { Impaired glucose tolerance (fasting } C B G<7 \mathrm{mmol} / \mathrm{L} \text { and } \\
\text { a } 2-\mathrm{h} \text { post glucose } C B G \geq 8.9 \mathrm{mmo} / \mathrm{L} \text { but }<12.2 \mathrm{mmol} / \mathrm{L} \text { ) }\end{array}$ & 17 & 5.0 & 24 & 5.9 & 0.60 \\
\hline $\begin{array}{l}\text { Diabetes (proof of previous diagnosis and/or fasting } \\
\text { CBG } \geq 7 \mathrm{mmol} / \mathrm{L} \text { and/or } 2-\mathrm{h} \text { post prandial } \\
\text { CBG value } \geq 12.2 \mathrm{mmol} / \mathrm{L} \text { ) }\end{array}$ & 47 & 13.8 & 48 & 11.7 & 0.40 \\
\hline Education & & & & & $<0.001$ \\
\hline Illiterate & 174 & 51.0 & 315 & 76.5 & \\
\hline Literate, less than primary school & 94 & 27.6 & 48 & 11.7 & \\
\hline Primary school & 59 & 17.3 & 46 & 11.2 & \\
\hline Secondary/post-secondary school & 14 & 4.1 & 3 & 0.7 & \\
\hline Wealth Index & & & & & $<0.001$ \\
\hline Low & 108 & 31.7 & 200 & 48.5 & \\
\hline Middle & 217 & 63.6 & 188 & 45.6 & \\
\hline High & 16 & 4.7 & 24 & 5.8 & \\
\hline Tobacco use & & & & & $<0.001$ \\
\hline Current users & 173 & 51.3 & 279 & 68.9 & \\
\hline Not current users & 164 & 48.7 & 126 & 31.1 & \\
\hline
\end{tabular}

$p$-values are for differences in means or proportions of each characteristic between sexes using two-sided Student's t-tests and Pearson chi-squared tests, respectively 
Table 2 Double burden of malnutrition characterization in a sample of adults from rural South India

\begin{tabular}{|c|c|c|c|c|c|}
\hline Double burden characterization & $\begin{array}{l}\text { Men } \\
\mathrm{n}\end{array}$ & $\%$ & $\begin{array}{l}\text { Women } \\
\mathrm{n}\end{array}$ & $\%$ & $\boldsymbol{p}$-value \\
\hline Anemia and overweight or obese & 44 & 13.1 & 94 & 23.1 & $<0.001$ \\
\hline Anemia and pre-diabetes & 8 & 2.4 & 25 & 6.2 & 0.01 \\
\hline Anemia and diabetes & 21 & 6.3 & 24 & 5.9 & 0.84 \\
\hline Anemia and hypertension & 40 & 12.0 & 67 & 16.6 & 0.07 \\
\hline Stunted and overweight & 43 & 12.6 & 54 & 13.3 & 0.79 \\
\hline Stunted and pre-diabetes & 7 & 2.1 & 15 & 3.7 & 0.19 \\
\hline Stunted and diabetes & 19 & 5.6 & 16 & 3.9 & 0.29 \\
\hline Stunted and hypertension & 32 & 9.5 & 40 & 9.9 & 0.85 \\
\hline
\end{tabular}

$p$-values are for differences in proportions between sexes using Pearson chi-squared test

affected a greater proportion of women (57.2\%) than men (35.2\%).

Double burden pairings were prevalent among participants (Table 2). Overall prevalence of co-morbid anemia and overweight or obesity was $23.1 \%$ among women and $13.1 \%$ among men. Meanwhile, prevalence of co-morbid anemia and pre-diabetes was $6.2 \%$ among women and $2.4 \%$ among men, and co-morbid anemia and diabetes was $5.9 \%$ among women and $6.3 \%$ among men. Only $12.9 \%$ of participants $(8.7 \%$ of women and $17.9 \%$ of men) did not have any indicator of either over- or undernutrition (diabetes, overweight, obesity, abdominal obesity, hypertension, stunted, anemia, or underweight), indicating a small proportion of the population were adequately nourished and cardio-metabolically healthy.

Descriptive characteristics of the study population by diagnostic category of DBP1 and DBP2 are displayed in Tables 3 and 4, respectively. A significant difference in means or proportions between categories of DBP1 was seen for several attributes, including age, sex, rurality, wealth index, physical activity habits, and dietary intake. Additionally, a significant difference in means or proportions between categories of DBP2 was seen for several characteristics, including age, sex, rurality, family history, religion, wealth index, physical activity, and dietary intake.

Several factors were associated with co-morbid anemia and overweight in age- and sex-adjusted logistic regression model (Table 5). High caste was associated with increased odds of both overweight and co-morbid anemia and overweight. Wealth index values were associated with increased odds of overweight and co-morbid anemia and overweight, indicating that wealthier individuals were at higher risk of these outcomes. Rurality index values were negatively associated with overweight and co-morbid anemia and overweight, indicating individuals from less rural households experienced a greater risk of having these conditions. Tobacco consumption (current use of $\mathrm{paan}^{1}$ or cigarettes) was negatively associated with co-morbid anemia and overweight. Finally, livestock ownership and meat intake were both negatively associated with co-morbid anemia and overweight.

Several factors were associated with co-morbid anemia and diabetes in the age- and sex-adjusted logistic regression model (Table 6). High caste was positively associated with co-morbid anemia and diabetes. Greater rurality index value was associated with lower odds of diabetes and co-occurrence of anemia and diabetes. Meanwhile, family history of diabetes was associated with much greater odds of diabetes and co-morbid anemia and diabetes.

\section{Discussion}

Indicators of over- and undernutrition were widespread, both at the population level and within individuals. Prevalence of most measures of over- and undernutrition in the study population were similar or higher than state-level rural averages and previous regional studies conducted in South India [7, 8, 41-44]. Underweight was more common among men, which is unusual for an Indian sample population [7, 44, 45]. Evidence suggests that anemia and underweight have been declining across India in the past decade, so timing of studies may account for differences in published data [7].

Results indicate that rural regions in South India may mirror patterns seen in urban India over the past two decades, with the burden of overweight and associated morbidities surpassing that of undernutrition [46]. The study population had similar or slightly higher prevalence of overweight and associated morbidities in comparison to previous studies in rural India and Tamil Nadu [41, 42]. As discussed elsewhere [47], this study recorded one of the highest regional burdens of diabetes in rural India at $10.8 \%$, which is higher than state-level estimates (7.8\% as measured by Anjana et al. 2011) [8] and most previous regional estimates (see Misra et al. 2011 for review of prevalence studies in rural India) [48], but was similar to a recent cross-sectional study conducted in clusters of villages in nearby Vellore, Tamil Nadu (11.2\%) [43]. Prevalence of overweight (34.3\% in men and $38.6 \%$ in women) was much higher than statelevel rural estimates in 2006 (22.5\% in men and $25.1 \%$ in women according to the National Nutritional Monitoring Board) [44], but similar to other recent regional studies in South India [41, 49]. High blood pressure (31.1\% in men and $28.8 \%$ in women) was more prevalent than state-level estimates (17.6\% among men and $11.5 \%$ in women as measured by IIPS) [7] and regional

\footnotetext{
${ }^{1}$ A preparation of betel leaf, areca nut, and tobacco that is chewed for its stimulant and psychoactive properties
} 
Table 3 Clinical, sociodemographic, and dietary characteristics by double burden diagnostic category in a sample of adults from rural South India

\begin{tabular}{|c|c|c|c|c|c|}
\hline Characteristic & $\begin{array}{l}\text { Category 1: Neither } \\
\text { anemia nor overweight } \\
(\boldsymbol{n}=250)\end{array}$ & $\begin{array}{l}\text { Category 2: } \\
\text { Anemia only } \\
(\boldsymbol{n}=218)\end{array}$ & $\begin{array}{l}\text { Category 3: Overweight } \\
\text { or obese only }(\boldsymbol{n}=145)\end{array}$ & $\begin{array}{l}\text { Category 4: Co-morbid anemia } \\
\text { and overweight or obese } \\
(\boldsymbol{n}=138)\end{array}$ & $\begin{array}{l}p \text {-value } \\
\text { for trend* }\end{array}$ \\
\hline \multicolumn{6}{|l|}{ Descriptive characteristics } \\
\hline Age & $44.9 \pm 15.0$ & $51.5 \pm 16.1$ & $45.5 \pm 11.7$ & $46.2 \pm 13.3$ & $\begin{array}{l}<.001^{\mathrm{a}, \mathrm{d}, \mathrm{e}} \\
\end{array}$ \\
\hline Women (\%) & 41.7 & 65.1 & 49.0 & 68.1 & $\begin{array}{l}< \\
0.001^{a, c, d, f}\end{array}$ \\
\hline Hypertension (\%) & 22.4 & 24.1 & 41.5 & 40.1 & $\begin{array}{l}< \\
0.001^{a, b, d, e}\end{array}$ \\
\hline Rurality Index & $-0.21 \pm 1.31$ & $-0.24 \pm 1.14$ & $-0.94 \pm 1.41$ & $-1.07 \pm 1.21$ & $\begin{array}{l}< \\
0.001^{b, c, d, e}\end{array}$ \\
\hline Current tobacco consumer (\%) & 44.1 & 44.7 & 34.7 & 25.7 & $0.001^{c, e}$ \\
\hline $\begin{array}{l}\text { Muslim (Hindu as referent) religion } \\
\text { (\%) }\end{array}$ & 3.6 & 1.8 & 5.5 & 5.1 & 0.24 \\
\hline \multicolumn{6}{|l|}{ Wealth and possession attributes } \\
\hline Wealth index & $11.00 \pm 4.31$ & $9.56 \pm 4.35$ & $12.17 \pm 4.81$ & $11.73 \pm 5.10$ & $\begin{array}{l}< \\
0.001^{\mathrm{a}, \mathrm{d}, \mathrm{e}}\end{array}$ \\
\hline High-quality (pucca) housing (\%) & 10.7 & 8.3 & 20.7 & 18.8 & $0.001^{b, d, e}$ \\
\hline Land ownership (acres) & $1.50 \pm 1.85$ & $1.20 \pm 1.54$ & $1.21 \pm 1.86$ & $1.07 \pm 1.99$ & 0.11 \\
\hline Livestock ownership (\%) & 51.8 & 46.3 & 34.5 & 25.5 & $\begin{array}{l}< \\
0.001^{\text {b.c.e }}\end{array}$ \\
\hline In-house tap water (\%) & 7.5 & 5.5 & 11.7 & 9.4 & 0.18 \\
\hline \multicolumn{6}{|l|}{ Physical activity habits } \\
\hline $\begin{array}{l}\text { Physical Activity (hours/day of } \\
\text { moderate physical activity) }\end{array}$ & $4.55 \pm 3.66$ & $3.98 \pm 3.43$ & $3.59 \pm 3.77$ & $3.38 \pm 3.77$ & $0.008^{c}$ \\
\hline Sedentary time (hours/day) & $4.06 \pm 2.50$ & $4.42 \pm 2.85$ & $4.76 \pm 2.91$ & $4.9 \pm 2.70$ & $0.009^{3}$ \\
\hline Television time (hours/day) & $1.33 \pm 1.26$ & $1.23 \pm 1.24$ & $1.68 \pm 1.36$ & $1.81 \pm 1.33$ & $\begin{array}{l}< \\
0.001^{c, d, e}\end{array}$ \\
\hline Labour occupation (\%) & 54.7 & 64.5 & 47.6 & 44.9 & $0.001^{\mathrm{d}, \mathrm{e}}$ \\
\hline \multicolumn{6}{|c|}{ Dietary intake (g/1000 kcal unless otherwise specified) } \\
\hline Current alcohol consumer (\%) & 52.3 & 41.7 & 49.7 & 44.2 & 0.10 \\
\hline Total energy intake (kcal/day) & $2436 \pm 868$ & $2307 \pm 634$ & $2436 \pm 694$ & $2353 \pm 643$ & 0.20 \\
\hline Carbohydrates & $179.8 \pm 15.6$ & $183.2 \pm 13.3$ & $176.3 \pm 14.7$ & $176.7 \pm 12.9$ & $<0.001^{\mathrm{d}, \mathrm{e}}$ \\
\hline Protein & $25.8 \pm 2.1$ & $25.3 \pm 1.8$ & $25.8 \pm 1.9$ & $25.7 \pm 1.7$ & $0.03^{1}$ \\
\hline Total fat & $19.2 \pm 5.5$ & $18.3 \pm 5.1$ & $20.9 \pm 5.0$ & $21.3 \pm 4.8$ & 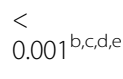 \\
\hline Dietary fibre & $22.4 \pm 5.2$ & $22.6 \pm 5.3$ & $21.3 \pm 5.0$ & $20.7 \pm 4.6$ & $\begin{array}{l}<.001^{c, d, e} \\
\end{array}$ \\
\hline Dairy products & $81.0 \pm 73.0$ & $75.0 \pm 65.4$ & $81.6 \pm 65.3$ & $89.2 \pm 65.1$ & 0.29 \\
\hline Pulses and legumes & $26.4 \pm 11.4$ & $26.2 \pm 12.1$ & $28.7 \pm 12.2$ & $29.2 \pm 10.7$ & 0.005 \\
\hline Meat and poultry & $3.8 \pm 4.9$ & $2.4 \pm 2.5$ & $3.4 \pm 03.9$ & $2.8 \pm 03.9$ & $<0.001^{a}$ \\
\hline Fruits and vegetables & $73.0 \pm 46.7$ & $68.7 \pm 42.4$ & $83.3 \pm 49.0$ & $87.2 \pm 56.1$ & $<0.001^{\mathrm{d}, \mathrm{e}}$ \\
\hline Refined grains & $63.6 \pm 34.3$ & $63.3 \pm 31.9$ & $71.5 \pm 27.0$ & $74.4 \pm 32.7$ & $0.001^{c, e}$ \\
\hline
\end{tabular}

*P-values are for Pearson's chi square for proportions and one-way analyses of variance (ANOVA) for means

${ }^{a}$ Category 1 versus 2 different to $\mathrm{p}<0.05$ with Sidak pairwise comparison; ${ }^{\mathrm{b}}$ Category 1 versus 3 different to $p<0.05$ with Sidak pairwise comparison; ${ }^{\mathrm{c}}$ Category 1 versus 4 different to $p<0.05$ with Sidak pairwise comparison; ${ }^{d}$ Category 2 versus 3 different to $p<0.05$ with Sidak pairwise comparison; ${ }^{e}$ Category 2 versus 4

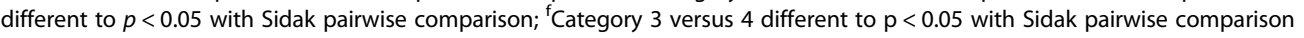


Table 4 Clinical, sociodemographic, and dietary characteristics by double burden diagnostic category in a sample of adults from rural South India

\begin{tabular}{|c|c|c|c|c|c|}
\hline Characteristic & $\begin{array}{l}\text { Category 1: Neither anemia } \\
\text { nor diabetes }(\boldsymbol{n}=348)\end{array}$ & $\begin{array}{l}\text { Category 2: } \\
\text { Anemia only }(\boldsymbol{n}= \\
\text { 313) }\end{array}$ & $\begin{array}{l}\text { Category } 3: \\
\text { Diabetes only } \\
(\boldsymbol{n}=46)\end{array}$ & $\begin{array}{l}\text { Category 4: Co-morbid } \\
\text { anemia and diabetes }(\boldsymbol{n}= \\
\text { 42) }\end{array}$ & $\begin{array}{l}p \text {-value } \\
\text { for trend* }\end{array}$ \\
\hline \multicolumn{6}{|l|}{ Descriptive characteristics } \\
\hline Age & $44.6 \pm 14.0$ & $48.7 \pm 15.4$ & $48.9 \pm 12.7$ & $54.9 \pm 13.4$ & $<0.001^{\mathrm{a}, \mathrm{c}}$ \\
\hline Women (\%) & 44.2 & 67.8 & 45.7 & 54.8 & $<0.001^{a, d}$ \\
\hline Hypertension (\%) & 25.8 & 28.2 & 56.5 & 46.3 & $<0.001^{b, c, d}$ \\
\hline Rurality Index & $0.14 \pm 1.77$ & $0.092 \pm 1.60$ & $-096 \pm 1.96$ & $-0.83 \pm 1.49$ & $\begin{array}{l}< \\
0.001^{b, c, d, e}\end{array}$ \\
\hline Current tobacco consumer (\%) & 41.2 & 37.2 & 37.0 & 38.1 & 0.76 \\
\hline Family history of diabetes (\%) & 7.7 & 7.6 & 36.9 & 28.6 & $<0.00^{\mathrm{b}, \mathrm{c}, \mathrm{d}, \mathrm{e}}$ \\
\hline $\begin{array}{l}\text { Muslim (Hindu as referent) } \\
\text { religion (\%) }\end{array}$ & 3.4 & 2.2 & 10.9 & 9.5 & $0.006^{\mathrm{d}}$ \\
\hline \multicolumn{6}{|l|}{ Wealth and possession attributes } \\
\hline Wealth index & $11.38 \pm 4.45$ & $10.39 \pm 4.71$ & $11.85 \pm 5.14$ & $10.50 \pm 5.22$ & 0.02 \\
\hline Pucca housing (\%) & 13.1 & 11.8 & 23.9 & 16.7 & 0.14 \\
\hline Land ownership (acres) & $1.42 \pm 1.83$ & $1.22 \pm 1.79$ & $1.18 \pm 2.04$ & $0.68 \pm 1.09$ & 0.06 \\
\hline In-house tap water (\%) & 7.1 & 6.4 & 23.9 & 11.9 & $<0.001^{\mathrm{b}, \mathrm{d}}$ \\
\hline \multicolumn{6}{|l|}{ Physical activity habits } \\
\hline $\begin{array}{l}\text { Physical Activity (hours/day of } \\
\text { moderate physical activity) }\end{array}$ & $4.47 \pm 3.73$ & $3.92 \pm 3.56$ & $2.16 \pm 3.00$ & $2.47 \pm 3.44$ & $<0.001^{b, c, d}$ \\
\hline Sedentary time (hours/day) & $4.19 \pm 2.63$ & $4.53 \pm 2.78$ & $5.38 \pm 2.87$ & $5.33 \pm 2.86$ & $0.007^{c . d}$ \\
\hline Television time (hours/day) & $1.45 \pm 1.31$ & $1.49 \pm 1.31$ & $1.55 \pm 1.29$ & $1.19 \pm 1.25$ & 0.57 \\
\hline Labour occupation (\%) & 53.0 & 58.8 & 45.7 & 42.9 & 0.09 \\
\hline Livestock ownership (\%) & 48 & 39.6 & 26.1 & 28.6 & $0.003^{b}$ \\
\hline \multicolumn{6}{|c|}{ Dietary intake (g/1000 kcal unless otherwise specified) } \\
\hline Current alcohol consumer (\%) & 51.6 & 43.6 & 50 & 35.7 & 0.08 \\
\hline Total energy intake (kcal/day) & $2451 \pm 829$ & $2349 \pm 649$ & $2324 \pm 626$ & $2153 \pm 519$ & 0.04 \\
\hline Carbohydrates & $179.2 \pm 14.8$ & $181.0 \pm 13.4$ & $174.1 \pm 18.2$ & $178.7 \pm 14.7$ & $0.02^{4}$ \\
\hline Protein & $25.8 \pm 02.1$ & $25.4 \pm 01.7$ & $25.0 \pm 01.9$ & $25.8 \pm 01.6$ & 0.06 \\
\hline Total fat & $19.7 \pm 5.3$ & $19.4 \pm 5.2$ & $21.3 \pm 5.5$ & $20.1 \pm 5.0$ & 0.16 \\
\hline Dietary fibre & $220.0 \pm 51.6$ & $219.6 \pm 81.6$ & $220.6 \pm 108.0$ & $217 \pm 63.9$ & 0.99 \\
\hline Dairy products & $79.2 \pm 71.4$ & $79.6 \pm 65.0$ & $95.3 \pm 58.9$ & $89.2 \pm 69.3$ & 0.38 \\
\hline Pulses and legumes & $27.5 \pm 11.6$ & $27.5 \pm 11.9$ & $28.3 \pm 13.3$ & $27.4 \pm 09.3$ & 0.97 \\
\hline Meat and poultry & $3.7 \pm 4.5$ & $2.6 \pm 3.1$ & $3.7 \pm 4.6$ & $2.5 \pm 3.2$ & $0.003^{\mathrm{a}}$ \\
\hline Fruits and vegetables & $77.0 \pm 48.3$ & $76.6 \pm 50.7$ & $74.9 \pm 43.3$ & $70.4 \pm 33.1$ & 0.86 \\
\hline Refined grains & $67.1 \pm 32.3$ & $76.6 \pm 50.7$ & $74.9 \pm 43.3$ & $70.4 \pm 33.1$ & 0.86 \\
\hline
\end{tabular}

*P-values are for Pearson's chi square for proportions and one-way analyses of variance (ANOVA) for means

${ }^{a}$ Category 1 versus 2 different to $\mathrm{p}<0.05$ with Sidak pairwise comparison; ${ }^{\mathrm{b}}$ Category 1 versus 3 different to $\mathrm{p}<0.05$ with Sidak pairwise comparison; ${ }^{\mathrm{c} C}$ ategory 1

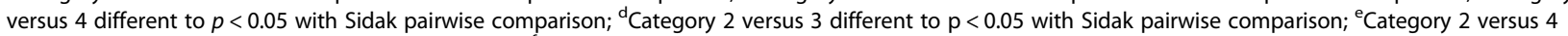

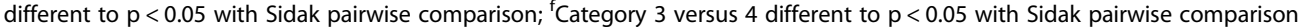

population studies $[43,50]$. Our results corroborate recent evidence suggesting that low-resource rural regions are experiencing high rates of obesity, diabetes, hypertension, and other indicators of over-nutrition.

As yet, few studies in India have reported on the emerging double burden of malnutrition, and even fewer have investigated individual-level co-occurrence of over- and undernutrition. Alarmingly, we found that $13.1 \%$ of men and $23.1 \%$ of women had co-occurring anemia and overweight, which was considerably higher than figures reported by Jones and colleagues in 2016 (1.3\% in men and $9 \%$ in women) in an urbanizing rural region of South India [21]. We also found that about half of all individuals with diabetes also had anemia. While no other 
Table 5 Factors associated with double burden categories in a multivariable logistic regression analysis in a sample of adults in rural Tamil Nadu, South India

\begin{tabular}{llll}
\hline & $\begin{array}{l}\text { Anemia only } \\
\text { OR }(95 \% \mathrm{Cl})\end{array}$ & Overweight only & Co-morbid anemia and overweight \\
\hline Age (continuous) & $1.03(1.02,1.05)^{\mathrm{a}}$ & $1.01(1.00,1.03)$ & $1.01(0.99,1.03)$ \\
Female sex (male as referent) & $3.0(2.03,4.46)^{\mathrm{a}}$ & $1.30(0.82,2.05)$ & $2.31(1.39,3.85)^{\mathrm{a}}$ \\
High caste (Brahmin) & - & $3.95(1.75,8.93)^{\mathrm{a}}$ & $3.17(1.34,7.49)^{\mathrm{a}}$ \\
Wealth index & - & $1.06(1.01,1.13)^{\mathrm{a}}$ & $1.05(1.00,1.12)^{\mathrm{b}}$ \\
Rurality index & - & $0.69(0.58,0.81)^{\mathrm{a}}$ & $0.69(0.56,0.85)^{\mathrm{a}}$ \\
Tobacco consumption & - & - & $0.55(0.32,0.96)^{\mathrm{b}}$ \\
Livestock ownership & - & - & $0.51(0.29,0.89)^{\mathrm{b}}$ \\
Meat and poultry intake $(\mathrm{g} / 1000 \mathrm{kcal})$ & - & - & $0.75(0.61,0.94)^{\mathrm{b}}$ \\
\hline
\end{tabular}

Only variables associated with one or more outcome level $(p<0.05)$ are displayed

The dependent variable is a multi-level outcome: $0=$ neither anemia nor overweight (referent, not shown); $1=$ anemia only; $2=$ overweight only; $3=$ both anemic and overweight

Definitions as follows: anemia, $\mathrm{Hb}<130 \mathrm{~g} / \mathrm{dL}$ for men, $<120 \mathrm{~g} / \mathrm{dL}$ for women; overweight, $\geq 23 \mathrm{~kg} / \mathrm{m}^{2}$

${ }^{a} p<0.01 ;{ }^{b}<<0.05 ;{ }^{c} p<0.1 ;{ }^{d} p<0.2$

studies have examined co-occurring anemia and diabetes in India, Jones and colleagues found prevalence of cooccurring anemia and metabolic syndrome (defined as three of five of abdominal obesity, high triglycerides, low HDL cholesterol, hypertension, or high blood glucose) was $2.8 \%$, including $1.2 \%$ among men and $4.5 \%$ among women [21].

To our knowledge, this is the first cross-sectional study to assess associations between individual-level double burden of malnutrition and a wide range of demographic, socio-economic, dietary, and lifestyle risk factors in a rural region of India using multivariable logistic regression models. Several factors were associated with double burden outcomes. Our results corroborate evidence from India and other LMICs including China and Burkina Faso that co-morbid anemia and overweight or diabetes affect a larger proportion of women than men [19, 21, 51]. In addition, female sex was associated with higher odds of co-morbid anemia and overweight in multivariable models. This may be driven by Indian women being at higher independent risk of anemia, overweight, and diabetes compared to men [21, 49, 52]. It should be noted that such findings may also reflect intra-household dynamics and gender inequities that disproportionately impact women's food intake and nutrition. For example, some studies suggest that men eat first in many Indian households, and that female children may be neglected in favour of male children [53-

Table 6 Factors associated with double burden categories in a multivariable logistic regression analysis in a sample of adults in rural Tamil Nadu, South India

\begin{tabular}{|c|c|c|c|}
\hline & $\begin{array}{l}\text { Anemia only, fully } \\
\text { adjusted model } \\
\text { OR (95\% Cl) }\end{array}$ & $\begin{array}{l}\text { Diabetes only, } \\
\text { fully adjusted model } \\
\text { OR ( } 95 \% \text { Cl) }\end{array}$ & $\begin{array}{l}\text { Co-morbid anemia and diabetes, } \\
\text { fully adjusted model } \\
\text { OR }(95 \% \mathrm{Cl})\end{array}$ \\
\hline Age (continuous) & $1.02(1.01,1.03)^{a}$ & $1.02(1.00,1.04)^{\mathrm{d}}$ & $1.08(1.05,1.11)^{\mathrm{a}}$ \\
\hline Female Sex (male as referent) & $2.73(1.97,3.79)^{a}$ & $1.43(0.61,2.11)$ & $1.04(0.49,2.20)$ \\
\hline Scheduled caste or tribe $(\mathrm{Y} / \mathrm{N})$ & - & $2.89(1.21,6.90)^{b}$ & - \\
\hline Seasonal migrant (Y/N) & $0.54(0.31,0.94)^{b}$ & - & - \\
\hline Livestock ownership (Y/N) & $0.68(0.49,0.94)^{b}$ & - & - \\
\hline Rurality index & - & - & $0.75(0.57,0.98)^{b}$ \\
\hline Family history of diabetes (Y/N) & - & $4.17(1.80,9.62)^{a}$ & $4.86(1.86,12.70)^{\mathrm{a}}$ \\
\hline Physical Activity (h/day moderate activity) & - & $0.85(0.76,0.96)^{a}$ & - \\
\hline Body Mass Index (standardized) & - & $1.87(1.25,2.81)^{\mathrm{a}}$ & $2.14(1.45,3.14)^{a}$ \\
\hline Waist circumference (standardized) & - & $1.68(1.09,2.57)^{\mathrm{b}}$ & - \\
\hline Meat and poultry intake (g/1000 kcal) & $0.87(0.78,0.98)^{b}$ & - & - \\
\hline
\end{tabular}

Only variables associated with one or more outcome level $(p<0.05)$ are displayed

The dependent variable is a multi-level outcome: $0=$ neither anemia nor diabetes (referent, not shown); $1=$ anemia only; $2=$ diabetes only; $3=$ both anemia and diabetes

Definitions as follows: anemia, $\mathrm{Hb}<130 \mathrm{~g} / \mathrm{dL}$ for men, $<120 \mathrm{~g} / \mathrm{dL}$ for women; diabetes, proof of previous diagnosis and/or CBG $\geq 7 \mathrm{mmol} / \mathrm{L}$ ( $\geq 126 \mathrm{mg} / \mathrm{dl}$ ) and/or a $2 \mathrm{~h}$ post prandial $C B G$ value $\geq 12.2 \mathrm{mmol} / \mathrm{L}(\geq 220 \mathrm{mg} / \mathrm{dL}) ;{ }^{\mathrm{a}} \mathrm{p}<0.01 ;{ }^{\mathrm{b}} \mathrm{p}<0.05 ;{ }^{c} \mathrm{p}<0.1 ;{ }^{\mathrm{d}} \mathrm{p}<0.2$ 
56]. Such inequities may exacerbate the double burden of malnutrition among women and explain the higher prevalence and co-occurrence of anemia, overweight, and diabetes compared to men.

Socio-economic status (SES) and caste in rural India are intricately linked, and several researchers concur that elevated SES and high caste are positively associated with higher risk of obesity and non-communicable diseases (NCDs) [57, 58]. In age- and sex-adjusted multivariable models, higher wealth index values were associated with greater odds of overweight and comorbid anemia and overweight. In addition, high caste (Brahmin caste) was associated with increased odds of co-morbid anemia and diabetes, while low caste (scheduled caste or tribe status) was associated with decreased odds of co-morbid anemia and overweight. These results indicate that individuals of higher SES and higher caste were more likely to suffer from the effects of simultaneous over- and undernutrition, perhaps due to dietary and lifestyle patterns associated with wealth and caste [59]. While the effects of caste on health and disease are complex, some evidence suggests that high caste households tend to have higher standards of living, increased income, greater access to sedentary pastimes, and increased usage of vehicles, all of which may impact the risk of obesity and NCDs [60,61]. While one might expect that higher caste and SES might reduce risk of anemia and co-morbid anemia due to improved food access [62], this does not appear to be true for this study population. Such findings correspond with previous studies that demonstrated a connection between wealth and a diet high in calories but low in micronutrients [63, 64]. Additionally, our results align with research from Jones and colleagues, who also found that their assetbased wealth index was associated with an increased odds of co-occurring anemia with overweight or metabolic syndrome [21].

The rise of NCDs in India is often attributed to urbanization. While our study region was primarily agricultural and was classified as rural by Census India definitions [65], we employed a rurality index to assess the impacts of remoteness and population density on measures of over- and undernutrition. We found strong negative associations between rurality and risk of obesity, diabetes, co-morbid anemia and obesity, and comorbid anemia and diabetes. These findings parallel previous research in India [21] and sub-Saharan Africa [20] and may reflect urbanization-induced characteristics in the food and physical environments that promote obesity, diabetes, and other cardio-metabolic diseases [38, 66]. Such characteristics may include convenient access to shops to purchase snack foods and sweetened beverages, reduced physical activity due to proximity of amenities, and social networks and employment opportunities contributing to elevated SES $[61,67,68]$. This is an important finding, as it likely reflects the considerable variability and health implications of socio-economic, lifestyle, and dietary patterns occurring within rural regions of South India. Further, these findings underscore the importance of more nuanced approach to examining the urban-rural continuum in India, perhaps by eliminating the rural/urban dichotomy of most censuses and population health studies in favour of validated rurality or urbanicity indices or categories $[69,70]$.

Studies from the United States have suggested that a "westernized" diet consisting of energy-dense, but micronutrient-poor foods, may contribute to concurrent obesity and micronutrient deficiencies [67]. India is undergoing a nutrition transition characterized by a decline in the per capita consumption of traditional whole grains (e.g. small millets, barley, and buckwheat) and a diversification of food consumption [71]. In some ways, this shift mirrors prior changes in many high-income countries, including increased intake of refined sugars, saturated fats, and animal products $[4,68]$. India's nutrition transition is driven by rising incomes, economic development, urbanization, increased access to processed foods, changing food preferences, and shifting agricultural patterns, all of which are influenced by government policy and market forces $[4,59]$. Of concern in rural regions is the increasing popularity of refined grains (e.g. polished white rice) which have been processed to eliminate the bran and germ, thus removing fibre, vitamins, and other compounds that may protect against micronutrient deficiencies, diabetes, and other NCDs [72]. Polished white rice consumption has increased due, in part, to national food programs such as the Public Distribution System (PDS), the Integrated Child Development Services (ICDS), and the Mid-Day Meal Scheme (MMS), all of which now fall under India's National Food Security Act (NFSA) of 2013 and promote rice and wheat as staple sources of calories [56, 73] While these food programs have notably contributed to reducing the burdens of food insecurity and acute malnutrition in India, they have been criticized for relying heavily on staple grain distribution, thereby contributing to diets high in refined carbohydrates, low in protein, and lacking in adequate nutritional quality to prevent micronutrient deficiencies [73-75]. Indeed, some studies have suggested that by improving access and affordability of refined grains, the PDS and MMS may be exacerbating the burden of overweight and diabetes in rural India [76-79]. However, it should be noted that the infrastructure of the PDS, ICDS, and MMS represents an important opportunity to simultaneously promote calorie adequacy and improved nutrition [79, 80]. To address the double burden of over- and undernutrition among poor populations in rural India, it is necessary to 
leverage the reach of the NFSA and associated social welfare programs to promote the consumption of whole grains and nutrient-dense foods [74]. In some regions, targeted pilot programs have distributed whole grains (e.g. small millets) through the PDS and have seen some preliminary success $[81,82]$. Such efforts should be applauded and expanded if the Government of India wishes to address the double burden of malnutrition and prevent costly future healthcare expenditures.

There is some evidence to suggest that micronutrient deficiencies may contribute to the development and exacerbation of NCDs, and conversely that NCDs may affect absorption of micronutrients, thus exacerbating micronutrient deficiency [83]. For example, micronutrients such as Vitamin $C$ and zinc have antioxidant effects, and oxidative stress has been linked to the development and prognosis of cardiovascular disease and diabetes [84, 85]. Evidence also suggests that obesity and some NCDs further exacerbate oxidative stress, and may interact with dietary deficiencies to produce worse health outcomes [86, 87]. Similarly, some studies indicates that inflammation caused by obesity and diabetes reduces iron absorption, which may contribute to iron-deficiency anemia in individuals with these conditions [88, 89]. Such complex physiological pathways may partially explain why body mass index and waist-hip-ratio were positively associated with co-morbid anemia and diabetes in the study population. In addition, the coexistence of underweight, anemia, and diabetes appears consistent with malnutrition-related diabetes or fibrocalculous pancreatic diabetes (FCPD), for which malnutrition and micronutrient deficiencies may be etiological factors [90]. It is possible that some individuals in the study sample were misdiagnosed with type 2 diabetes when they in fact suffered from FCPD; however, considering the low prevalence of FCPD in other regions of South India (e.g. $0.019 \%$ in urban Chennai and $0.13 \%$ in rural Kerala), misclassification in this population was likely nonexistent or negligible [90-92]. Clearly, there are several potential links between nutrition intake, micronutrient deficiency and NCDs that need to be explored in further detail and may explain the high prevalence of co-morbidity in the present study.

The findings of this study are relevant to public health and clinical practice. High prevalence of co-morbid overand undernutrition underscore the importance of public health programs, policies, and healthcare practitioners to promote education, availability, and affordability of healthy diets and lifestyle patterns that simultaneously improve dietary deficiencies and reduce burdens of NCDs. Establishing healthy food environments, simultaneous screening and health monitoring of malnutrition and cardio-metabolic health outcomes, and promoting evidence-based and culturally-sensitive behaviour change may be integral to public health approaches [20]. Our study findings suggest that screening and interventions aiming to reduce the individual-level double burden of malnutrition in India should target women living in moderately rural and urbanizing regions with a family history of metabolic disorders. Our analyses indicate that livestock ownership and meat and poultry consumption were associated with reduced odds of co-morbid overweight and anemia, suggesting that dietary interventions, and in particular improved access to nutrient-dense foods, may be beneficial to prevent or reduce this double burden pairing. Meanwhile, healthcare professionals should consider the risk of iron deficiency and anemia in all patients with obesity or cardio-metabolic disorders before recommending dietary and lifestyle changes. Our findings provide further evidence cautioning against interventions to reduce obesity through caloric restriction, as this may exacerbate nutrient deficiencies if the patient's diet is nutritionally poor [93]. Due to the limited research on the double burden of malnutrition in India, there is a need for further observational and experimental data to determine the effectiveness of policy, public health interventions, and clinical practices in preventing and managing co-occurring over- and undernutrition.

This study had several limitations. Although we used systematic random sampling to ensure internal validity, the sample is likely not representative of the state or national rural population, and thus our findings cannot be generalized to other populations in India. Crosssectional study designs have known limitations regarding causal interpretations of observed associations and potential confounding bias. In addition, although we mostly employed standardized and validated data collection tools, there were some notable exceptions. The asset-based wealth index was modified from the one used by the NFHS and was not validated against other measures of wealth. The rurality index was adapted from one developed for health research in the United States, but was not previously validated for use in India [39]. Although the FFQ was validated for use in rural Tamil Nadu [28], the limitations of FFQs are well-documented and include a susceptibility to social desirability bias and a tendency to overestimate food intakes [28]. Finally, due to limited access to laboratories and transportation constraints, we measured CBG, which has a wider coefficient of variation than venous plasma BG [8]. However, previous studies have shown good correlation between CBG and venous plasma estimations, and the WHO recommends CBG in low-resource settings [31].

\section{Conclusion}

Over- and undernutrition should not be considered distinct conditions at opposite ends of the nutrition spectrum; rather, they may occur simultaneously in 
populations, households, and individuals. While the burden of chronic disease in India was previously socially and geographically segregated, our results suggest that as the nutrition transition progresses, obesity and associated cardiometabolic outcomes are increasingly affecting poor and rural populations. We found high prevalence of co-morbid anemia and overweight, as well as comorbid anemia and diabetes, indicating that the double burden of malnutrition is now a severe public health concern in rural regions of South India. Women are in this rural region of South India bear a larger burden of anemia, excessive adiposity, and associated cardiometabolic illness. Such burdens are likely further exacerbated by low literacy and education among rural women. The positive association of household wealth and decreased rurality with these conditions suggests that cooccurring over- and undernutrition will not decline with economic development and urbanization, and substantial investments in rural education and health services are likely necessary. The double burden of malnutrition in rural India is a public health crisis that must be addressed through research, healthy policy, public health education and programming, and clinical practice, particularly in the context of a rapid nutrition transition.

\section{Abbreviations}

BMI: Body Mass Index; CBG: Capillary Blood Glucose; DBP: Double Burden Pair; FCPD: Fibrocalculous Pancreatic Diabetes; FFQ: Food Frequency Questionnaire; GPAQ: Global Physical Activity Questionnaire; ICDS: Integrated Child Development Services; IFG: Impaired Fasting Glucose; IGT: Impaired Glucose Tolerance; IIPS: International Institute of Population Sciences; LMICs: Low- and Middle-Income Countries; MMS: Mid-Day Meal Scheme; NCDs: Noncommunicable Diseases; NFHS: National Family Health Survey; NFSA: National Food Security Act; SES: Socioeconomic Status; PDS: Public Distribution System; WHO: World Health Organization

\section{Acknowledgements}

The authors thank the dedicated field research team that made this study possible. T. Madhe Gowda, N. Kodhai Priya, Priscilla Dhanapal, Dr. Vikas Kumar, and R. Rajesh overcame many challenges to ensure the field research was conducted smoothly. The authors also thank all of the individuals who participated in the study for their willingness to share their lives with the research team. The authors are very grateful to the numerous institutions and organizations that provided support during data collection and analysis. The Development for Humane Action Foundation and the Madras Diabetes Research Foundation provided logistical assistance for all field research. We also thank Cole Heasley for his editorial support and Candice Randle for her assistance producing the study site map.

\section{Authors' contributions}

$M L$ conceived of the study, organized and supervised all field research, conducted data entry and analysis, and prepared the manuscript. SH helped to develop the research questionnaire and provided extensive feedback on the manuscript. WD assisted with questionnaire development, provided feedback on data analysis methods, and edited the manuscript. KP provided contacts for field research, input into the questionnaire and methods, and edited the manuscript. His insight into the local research environment was extremely valuable. CD's expertise as an epidemiologist informed sample selection, questionnaire development, statistical analyses, and reporting of results. She also provided feedback on the manuscript throughout the writing process. All authors read and approved the final manuscript.

\section{Funding}

Funding for this study was received from the International Development Research Centre (IDRC) and the Department of Foreign Affairs, Trade, and Development (now Global Affairs Canada) for their financial support through the Canadian International Food Security Research Fund. IDRC also provided financial support through their doctoral research award program. Funding throughout the data analyses and writing processes was provided by the Canadian Institutes of Health Research through the Vanier Canada Graduate Scholars program. None of the funders played a role in study design, data collection, data analysis, or writing the manuscript.

\section{Availability of data and materials}

The datasets generated and analysed during the current study are not publicly available due to research participant privacy/consent agreements. Any request for raw data will be reviewed by the corresponding author.

\section{Ethics approval and consent to participate}

This study received ethics clearance for research on human participants from the University of Guelph research ethics board (certificate 12MY023). Permission for the study was granted by the High Commission of India in Ottawa, Canada. Upon arrival to the research site, and prior to the recruitment process, we approached local authorities (panchayat councils, local police officials, and hospital medical staff) and sought and obtained written permission to carry out the study. Informed verbal consent was obtained from all research participants prior to enrollment and throughout the study. Verbal consent was sought in lieu of written consent due to the low literacy rate of research participants, and this consent process was approved by the University of Guelph research ethics board.

\section{Consent for publication}

No individual data are presented in the manuscript.

\section{Competing interests}

The authors declare no competing interests.

\section{Author details}

${ }^{1}$ Department of Population Medicine, University of Guelph, Guelph, ON, Canada. ${ }^{2}$ School of Public Health and Social Policy, University of Victoria, Victoria, BC, Canada. ${ }^{3}$ Department of Sociology and Anthropology, University of Guelph, Guelph, ON, Canada. ${ }^{4}$ School of Public Health and Health Systems, University of Waterloo, Waterloo, ON, Canada. ${ }^{5}$ Department of International Development Studies, Menno Simons College, University of Winnipeg, Winnipeg, MB, Canada.

Received: 21 August 2019 Accepted: 8 April 2020

Published online: 13 May 2020

References

1. Popkin BM, Adair LS, Ng SW. Global nutrition transition and the pandemic of obesity in developing countries. Nutr Rev. 2012;70(1):3-21.

2. Doak CM, Adair LS, Bentley M, Monteiro C, Popkin BM. The dual burden household and the nutrition transition paradox. Int J Obes. 2005;29(1): 129-36.

3. Popkin BM. The nutrition transition and its health implications in lowerincome countries. Public Health Nutr. 1998;1(1):5-21.

4. Shetty PS. Nutrition transition in India. Public Health Nutr. 2002;5(1A):175-82

5. Yadav K, Krishnan A. Changing patterns of diet, physical activity and obesity among urban, rural and slum populations in North India. Obes Rev. 2008; 9(5):400-8.

6. Ahirwar R, Mondal PR. Prevalence of obesity in India: a systematic review. Diabetes Metab Syndr Clin Res Rev. 2019;13:318-21.

7. International Institute for Population Sciences. National Family Health Survey-4, State fact sheet Madhya Pradesh, 2015-16: India. Mumbai: IIPS; 2017. Available from: http://rchiips.org/NFHS/pdf/NFHS4/India.pdf. [cited 2019 May 23].

8. Anjana RM, Pradeepa R, Deepa M, Datta M, Sudha V, Unnikrishnan R, et al Prevalence of diabetes and prediabetes (impaired fasting glucose and/or impaired glucose tolerance) in urban and rural India: phase I results of the Indian Council of Medical Research-INdia DIABetes (ICMR-INDIAB) study. Diabetologia. 2011;54(12):3022-7. 
9. Bharati DR, Pal R, Kar S, Rekha R, Yamuna TV, Basu M. Prevalence and determinants of diabetes mellitus in Puducherry, South India. J Pharm Bioallied Sci. 2011;3(4):513-8 Available from: http://www.ncbi.nlm.nih.gov/ pubmed/22219584. [cited 2019 Jul 23].

10. Mohan V, Deepa M, Deepa R, Shanthirani CS, Farooq S, Ganesan A, et al. Secular trends in the prevalence of diabetes and impaired glucose tolerance in urban South India - the Chennai urban rural epidemiology study (CURES-17). Diabetologia. 2006:49:1175-8.

11. Centers for Disease Control and Prevention. CDC India Fact Sheet. 2015. Available from: https://www.cdc.gov/globalhealth/countries/india/pdf/india. pdf. [cited 2017 Feb 16].

12. Food and Agricultre Organization. The State of Food Insecurity in the World. 2014. Available from: http://www.fao.org/publications/sofi/2014/en/. [cited 2017 Feb 19].

13. United Nations Department of Economic and Social Affairs Population Division. World Urbanization Prospects: The 2018 Revision, Online Edition. 2018. Available from: https://esa.un.org/unpd/wup/Publications.

14. Caballero B. A nutrition paradox - underweight and obesity in developing countries. N Engl J Med. 2005;325(15):1514-6.

15. Duran $P$, Caballero $B$, de Onis $M$. The association between stunting and overweight in Latin American and Caribbean preschool children. Food Nutr Bull. 2006;27(4):300-5.

16. Pomeroy E, Stock JT, Stanojevic S, Miranda JJ, Cole TJ, Wells JCK. Stunting, adiposity, and the individual-level "dual burden" among urban lowland and rural highland Peruvian children. Am J Hum Biol. 2014;26(4):481-90.

17. Ramachandran P. The double burden of malnutrition in India. Double burden of malnutrition in developing countries; 2006. p. 99-161. Available from: ftp:// ftp.fao.org/docrep/fao/009/a0442e/a0442e00.pdf. [cited 2017 Mar 29].

18. Khan NC, Khoi HH. Double burden of malnutrition: the Vietnamese perspective. Asia Pac J Clin Nutr. 2008;17(Suppl 1):116-8.

19. Zeba AN, Delisle HF, Renier G, Savadogo B, Baya B. The double burden of malnutrition and cardiometabolic risk widens the gender and socioeconomic health gap: a study among adults in Burkina Faso (West Africa). Public Health Nutr. 2012;15(12):2210-9.

20. Jones AD, Acharya Y, Galway LP. Urbanicity gradients are associated with the household- and individual-level double burden of malnutrition in subSaharan Africa. J Nutr. 2016;146(6):1257-67.

21. Jones AD, Hayter AKM, Baker CP, Prabhakaran P, Gupta V, Kulkarni B, et al. The co-occurrence of anemia and cardiometabolic disease risk demonstrates sex-specific sociodemographic patterning in an urbanizing rural region of southern India. Eur J Clin Nutr. 2016;70(3):364-72.

22. Garrett $J$, Ruel MT. Stunted child-overweight mother pairs: prevalence and association with economic development and urbanization. Food Nutr Bull. 2005;26(2):209-21.

23. Subramanian S, Perkins JM, Khan KT. Do burdens of underweight and overweight coexist among lower socioeconomic groups in India? Am J Clin Nutr. 2009;90(2):369-76.

24. Srivastava DK, Shanmugam KR, Bhujanga Rao C. MDGs-based poverty reduction strategy for Tamil Nadu. Chennai: Madras School of Economics; 2010.

25. Karthikeyan M, Jena D, Patel K, Khadka K, Devkota R, Samaratunga H, et al. Baseline survey in project sites: A report as a part of "'Revalorizing small millets in the rainfed regions of South Asia (RESMISA)."' India, Nepal, Sri Lanka and Canada: DHAN Foundation, Arthacharya Foundation, Local Initiatives for Biodiversity, Research and Development (LIBIRD) and Canadian Mennonite University; 2012.

26. Little M, Humphries S, Patel K, Dewey C. Factors associated with BMI, underweight, overweight, and obesity among adults in a population of rural South India: a crosssectional study. BMC Obes. 2016;3. Article number: 12.

27. World Health Organization. WHO STEPS surveillance manual: the WHO STEPwise approach to chronic disease risk factor surveillance; 2003. p. 10-4. Available from: http://www.who.int/ncd_surveillance. [cited 2017 Mar 4].

28. Sudha V, Radhika G, Sathya RM, Ganesan A, Mohan V. Reproducibility and validity of an interviewer-administered semi-quantitative food frequency questionnaire to assess dietary intake of urban adults in southern India. Int J Food Sci Nutr. 2006;57(7-8):481-93.

29. World Health Organization. Global Physical Activity Questionnaire Analysis Guide GPAQ Analysis Guide Global Physical Activity Questionnaire (GPAQ) Analysis Guide. 2011. Available from: http://www.who.int/chp/steps/GPAQ/ en/index.html. [cited 2013 Nov 10].
30. Anjana RM, Pradeepa R, Deepa M, Datta M, Sudha V, Unnikrishnan R, et al. The Indian Council of Medical Research-India Diabetes (ICMR-INDIAB) study: methodological details. J Diabetes Sci Technol. 2011;5(4):906-14.

31. World Health Organization, International Diabetes Federaton. Definition and diagnosis of diabetes mellitus and intermediate hyperglycemia. 2006. Available from: http://www.who.int/diabetes/publications/Definition and diagnosis of diabetes_new.pdf. [cited 2013 Nov 29].

32. World Health Organization. The global epidemic. IOTF report. 2010. Available from: http://www.iaso.org/iotf/obesity/obesitytheglobalepidemic/. [cited 2015 Feb 10].

33. World Health Organization. The Asia-Pacific perspective: Redefining obesity and its treatment. 2000. Available from: http://www.wpro.who.int/nutrition/ documents/docs/Redefiningobesity.pdf. [cited 2017 May 4].

34. Coly AN, Milet J, Diallo A, Ndiaye T, Bénéfice E, Simondon F, et al. Preschool stunting, adolescent migration, catch-up growth, and adult height in young senegalese men and women of rural origin. J Nutr. 2006;136(9):2412-20.

35. National Centre for Health Statistics. CDC Growth Charts: United States. Atlanta, GA: National Center for Health Statistics. 2000Available from: https:// www.cdc.gov/growthcharts/index.htm. [cited 2019 May 30].

36. Chobanian AV, Bakris GL, Black HR, Cushman WC. Green L a, Izzo JL, et al. the seventh report of the joint National Committee on prevention, detection, evaluation, and treatment of high blood pressure: the JNC 7 report. JAMA. 2003;289:2560-71.

37. International Institute for Population Sciences. National Family Health Survey (NFHS-2). Mumbai: IIPS; 2000. Available from: http://www.dhsprogram.com/ pubs/pdf/FRIND2/FRIND2.pdf. [cited 2017 Feb 16].

38. Ebrahim S, Kinra S, Bowen L, Andersen E, Ben-Shlomo Y, Lyngdoh T, et al. The effect of rural-to-urban migration on obesity and diabetes in india: A cross-sectional study. PLoS Med. 2010;7(4).

39. Weinert C, Boik RJ. MSU Rurality index: development and evaluation. Res Nurs Health. 1995;18(5):453-64.

40. Government of India. Sample Registration System Statistical Report. 2011. Available from: http://www.censusindia.gov.in/vital_statistics/SRS_Reports. html. [cited 2015 Feb 20].

41. Kaur P, Rao SR, Radhakrishnan E, Ramachandran R, Venkatachalam R, Gupte MD. High prevalence of tobacco use, alcohol use and overweight in a rural population in Tamil Nadu, India. J Postgrad Med. 2011;57(1):9-15.

42. Selvaraj P, Irulankudi S, Selvaraj P. A study of the prevalence of overweight, obesity, and their associations with socioeconomic status among young men residing in a rural area, Kancheepuram District, Tamil Nadu, India. Int J Med Sci Public Heal. 2017;6(12):1670-4.

43. Oommen AM, Abraham VJ, George K, Jose VJ. Prevalence of risk factors for non-communicable diseases in rural \& urban Tamil Nadu. Indian J Med Res. 2016;144(3):460-71.

44. National Nutrition Monitoring Bureau. Diet and nutritional status of population and prevalence of hypertension among adults in rural areas. 2006. Available from: http://nnmbindia.org/nnmbreport06nov20.pdf. [cited 2017 Feb 8].

45. Samuel P, Antonisamy B, Raghupathy P, Richard J, Fall CHD. Socio-economic status and cardiovascular risk factors in rural and urban areas of Vellore, Tamilnadu, South India. Int J Epidemiol. 2012;41(5):1315-27.

46. Misra A, Singhal N, Sivakumar B, Bhagat N, Jaiswal A, Khurana L. Nutrition transition in India: secular trends in dietary intake and their relationship to diet-related non-communicable diseases. J Diabetes. 2011;3(4):278-92.

47. Little M, Humphries S, Patel K, Dodd W, Dewey C. Factors associated with glucose tolerance, pre-diabetes, and type 2 diabetes in a rural community of south India: A cross-sectional study. Diabetol Metab Syndr. 2016;8(1).

48. Misra P, Upadhyay RP, Misra A, Anand K. A review of the epidemiology of diabetes in rural India. Diabetes Res Clin Pract. 2011;92(3):303-11.

49. Gupta S, Singh Z, Purty A, Kar M, Vedapriya D, Mahajan P, et al. Diabetes prevalence and its risk factors in rural area of Tamil Nadu. Indian J Community Med. 2010;35(3):396

50. Venkatachalam J, Vishnu R, Muthu T, Samuel A, Singh Z. Prevalence and determinants of systemic hypertension among 15-year and older respondents in a rural area of Kancheepuram district, Tamil Nadu - a crosssectional study. Int J Med Sci Public Heal. 2016;5(4):1433-8.

51. Shi Z, Hu X, Yuan B, Hu G, Pan X, Holmboe-Ottesen G. Coexistence of anaemia and the metabolic syndrome in adults in Jiangsu. China. Asia Pac J Clin Nutr. 2008;17(3):505-13.

52. De Benoist B, Mclean E, Egli I, Cogswell M. Worldwide prevalence of anaemia 1993-2005 WHO global database on anaemia [Internet]. Geneva: 
WHO; 2008. Available from: http://apps.who.int/iris/bitstream/10665/43 894/1/9789241596657_eng.pdf. [cited 2017 Apr 3].

53. Barcellos SH, Carvalho LS, Lleras-Muney A. Child gender and parental investments in India: are boys and girls treated differently? Am Econ J Appl Econ. 2014;6(1):157-89.

54. Jere Behrman BR, Jodha S, Von Oppen M, Muller R, Walker-and Anil Deolalikar T, Birdsall N. Intrahousehold allocation of nutrients in Rurral India: are boys favored? Do parents exhibit inequality evasion? Oxf Econ Pap 1988;40:32-54

55. Coffey D. When women eat last. The Hindu. 2017. Available from: https:// www.thehindu.com/opinion/op-ed/When-women-eat-last/article16978948. ece?homepage=true, [cited 2017 Jun 17].

56. Desai S, Vanneman R. Enhancing Nutrition Security via India's National Food Security Act: Using an Axe instead of a Scalpel? India Policy Forum [papers] India Policy Forum Conf. 2015;11:67.

57. Kinra S, Bowen LJ, Lyngdoh T, Prabhakaran D, Reddy KS, Ramakrishnan L, et al. Sociodemographic patterning of non-communicable disease risk factors in rural India: A cross sectional study. BMJ. 2010;341(7776).

58. Zaman J, Patel A, Jan S, Hillis GS, Raju PK, Neal B, et al. Socio-economic distribution of cardiovascular risk factors and knowledge in rural India. Int J Epidemiol. 2012:41:302-14.

59. Mohan V, Sandeep S, Deepa R, Shah B, Varghese C. Epidemiology of type 2 diabetes: Indian scenario. Indian J Med Res. 2007;125(3)

60. Adinatesh K, Prashant K. A study of prevalence of childhood obesity among school children in Karimnagar town. MRIMS J Heal Sci. 2013;1(1):8-11.

61. Dodd W, King N, Humphries S, Little M, Dewey C. Self-reported morbidity and health service utilization in rural Tamil Nadu. India Soc Sci Med. 2016; 161:118-25.

62. Bentley ME, Griffiths PL. The burden of anemia among women in India. Eur J Clin Nutr. 2003:57(1):52-60.

63. Aloia CR, Gasevic D, Yusuf S, Teo K, Chockalingam A, Patro BK, et al. Differences in fast food consumption between individuals of high and low socio-economic status in Chandigarh, India. Can J Diabetes. 2011;35(2).

64. Deaton A, Dréze J. Food and Nutrition in India: Facts and Interpretations. Econ Polit Wkly. 2009:44-7.

65. Government of India. Census Terms. 2011. Available from: http:// censusindia.gov.in/Data_Products/Library/Indian_perceptive_link/Census_ Terms_link/censusterms.html. [cited 2015 May 31].

66. Allender S, Lacey B, Webster P, Rayner M, Deepa M, Scarborough P, et al. Level of urbanization and noncommunicable disease risk factors in Tamil Nadu, India. Bull World Health Organ. 2010;88(4):297-304.

67. Turner C, Kalamatianou S, Drewnowski A, Kulkarni B, Kinra S, Kadiyala S. Food environment research in low-and middle-income countries: a systematic scoping review. Adv Nutr. 2019;0:1-11.

68. Zhou M, Tan S, Tao Y, Lu Y, Zhang Z, Zhang L, et al. Neighborhood socioeconomics, food environment and land use determinants of public health: isolating the relative importance for essential policy insights. Land Use Policy. 2017;68:246-53.

69. Vlahov D, Galea S. Urbanization, urbanicity, and health. J Urban Heal. 2002; 79(4 Supp:1-12).

70. Cyril S, Oldroyd JC, Renzaho A. Urbanisation, urbanicity, and health: a systematic review of the reliability and validity of urbanicity scales. BMC Public Health. 2013;13:513.

71. Deepa M, Anjana RM, Mohan V. Role of lifestyle factors in the epidemic of diabetes: lessons learnt from India. Eur J Clin Nutr. 2017;71(7):825.

72. Cordain L, Eaton SB, Sebastian A, Mann N, Lindeberg S, Watkins BA, et al. Origins and evolution of the Western diet. Am J Clin Nutr. 2005;81(2):341-54.

73. Kumar P, Dey MM. Long-term changes in Indian food basket and nutrition. Econ Polit Wkly. 2007;42(35):3567-72.

74. Pingali P, Mittra B, Rahman A. The bumpy road from food to nutrition security - slow evolution of India's food policy. Glob Food Sec. 2017;15:77-84.

75. Mohan V, Radhika G, Vijayalakshmi P, Sudha V. Can the diabetes/ cardiovascular disease epidemic in India be explained, at least in part, by excess refined grain (rice) intake? Indian J med res. 2010;131:369-372.

76. Little M, Humphries S, Patel K, Dewey C. Decoding the type 2 Diabetes epidemic in rural India. Med Anthropol Cross Cult Stud Heal IIIn. 2017;36(2): 96-110

77. Ministry of Human Resource Development. Performance Audit of Mid Day Meal Scheme [Internet]. 2015. Available from: http://www. indiaenvironmentportal.org.in/files/file/performance audit of mid day meal scheme.pdf. [cited 2017 Feb 5].
78. Pingali P, Aiyar A, Abraham M, Rahman A. Indian food systems towards 2050: challenges and opportunities. In: Transforming food Systems for a Rising India. Cham: Palgrave Macmillan; 2019. p. 1-14.

79. Harriss-White B. Nutrition and its politics in Tamil Nadu. South Asia Res. 2004;24(1):51-71 Available from: www.sagepublications.com.

80. Khera R. Revival of the public distribution system: evidence and explanations. Econ Polit Wkly. 2011;46(44-45):36-50.

81. Thow AM, Kadiyala S, Khandelwal S, Menon P, Downs S, Reddy KS. Toward food policy for the dual burden of malnutrition: an exploratory policy space analysis in India. Food Nutr Bull. 2016;37(3):261-74.

82. Raju S, Rampal P, Bhavani RV, Rajshekar SC. Introduction of millets into the public distribution system: lessons from Karnataka. Journal. 2018;8(2):120-36.

83. Eckhardt CL, Torheim LE, Monterrubio E, Barquera S, Ruel MT. The overlap of overweight and anaemia among women in three countries undergoing the nutrition transition. Eur J Clin Nutr. 2008 Feb;62(2):238-46.

84. Lakshmi SW, Padmaja G, Kuppusamy P, Kutala VK. Oxidative stress in cardiovascular disease. Indian J Biochem Biophys. 2009 Dec;46(6):421-40.

85. Rahimi R, Nikfar S, Larijani B, Abdollahi M. A review on the role of antioxidants in the management of diabetes and its complications. Biomed Pharmacother. 2005;59:365-73.

86. Furukawa S, Fujita T, Shimabukuro M, Shimomura I, Iwaki M, Matsuda M, et al. Increased oxidative stress in obesity and its impact on metabolic syndrome. J Clin Invest. 2004;114(12):1752-61.

87. Thompson KH, Godin DV. Micronutrients and antioxidants in the progression of diabetes. Nutr Res. 1995;15(9):1377-410.

88. Aigner $\mathrm{E}$, Feldman A, Datz C. Obesity as an emerging risk factor for iron deficiency. Nutrients. 2014;6(9):3587-600.

89. Zimmermann MB, Zeder C, Muthayya S, Winichagoon P, Chaouki N, Aeberli I, et al. Adiposity in women and children from transition countries predicts decreased iron absorption, iron deficiency and a reduced response to iron fortification. Int J Obes. 2008;32(7):1098-104.

90. Mohan V, Nagalotimath SJ, Yajnik CS, Tripathy BB. Fibrocalculous pancreatic diabetes. Diabetes Metab Rev. 1998, 14;(2):153-70 Available from: http:// www.ncbi.nlm.nih.gov/pubmed/9679668. [cited 2019 Jul 23].

91. Balaji LN, Tandon RK, Tandon BN, Banks PA. Prevalence and clinical features of chronic pancreatitis in southern India. Int J Pancreatol. 1994;15(1):29-34.

92. Mohan V, Faroog S, Deepa M. Prevalence of fibrocalculous pancreatic diabetes in Chennai in South India. JOP. 2008;9(4):489-92.

93. Gartner A, El Ati J, Traissac P, Bour A, Berger J, et al. A double burden of overall or central adiposity and anemia or iron deficiency is prevalent but with little socioeconomic patterning among Moroccan and Tunisian urban women. J Nutr. 2014;144(1):87-97.

\section{Publisher's Note}

Springer Nature remains neutral with regard to jurisdictional claims in published maps and institutional affiliations.

Ready to submit your research? Choose BMC and benefit from:

- fast, convenient online submission

- thorough peer review by experienced researchers in your field

- rapid publication on acceptance

- support for research data, including large and complex data types

- gold Open Access which fosters wider collaboration and increased citations

- maximum visibility for your research: over $100 \mathrm{M}$ website views per year

At BMC, research is always in progress.

Learn more biomedcentral.com/submissions 